Dhaka Univ. J. Biol. Sci. 27(2): 113-123, 2018 (July)

\title{
CROP RESPONSE TO RESIDUAL EFFECTS OF BASIC SLAG, AGGREGATE SIZE AND GROUNDWATER LEVEL TREATED ACID SULFATE SOILS
}

\author{
Monija Manjur, Sonia Hossain* and Md. Harunor Rashid Khan \\ Department of Soil, Water and Environment, University of Dhaka. Dhaka-1000, Bangladesh
}

Key words: Acid sulfate soils, Growth and yield parameters, Rice

\begin{abstract}
A pot experiment with two acid sulfate soils of Badarkhali and Cheringa series were performed. After 18 years of fallow period in 2016, a crop trial was done in order to evaluate the response of rice plant without giving additional treatments. The average maximum temperature during the experimental period was $33.2^{\circ} \mathrm{C}$ and average rainfall was $57 \mathrm{~mm}$. Two cultivars of rice BRRI 48 and BRRI hybrid dhan 06 showed the tallest plant height of 115 $\mathrm{cm}$ and tillers 6.31 in numbers/plant on an average in both the soils. Panicle length was $16.5 \mathrm{~cm}, 1000$-grain weight $22 \mathrm{~g}$, grain yield $4.72 \mathrm{~g} / \mathrm{m}^{2}$ and harvest index was 0.01 on average in both the soils. The experiment indicates that soil condition for crop growth possesses good quality after a long time and growth and yield parameters found satisfactory and significant $(\mathrm{p} \leq 0.05)$.
\end{abstract}

\section{Introduction}

Acid sulfate soils (ASSs) impose two faced problems - acidity and salinity, in terms of crop production. Given the mounting pressure on global ecosystems, the food production increase must be achieved in a sustainable and environmentally sound way ${ }^{(1)}$. Acid sulfate soils affect more than 100 million hectares ( $\mathrm{M}$ ha) of land worldwide of which about $0.7 \mathrm{M}$ ha occurs in the coastal areas where crop production is very low; somewhere the lands are unproductive ${ }^{(2)}$. In Bangladesh, acid sulfate soils were first recognized in the coastal areas. In Chittagong coastal belt it is locally known as "Kosh" soil. Fertility level of these soils, specially $\mathrm{N}$ and $\mathrm{P}$ content is very low to low ${ }^{(3)}$.

The rapid increase of population, development of economic infrastructures and urbanization are snatching agricultural lands. Using marginal and problem soils through proper reclamation can alleviate this problem. Successful reclamation of the ASSs may result in the development of productive fields for crop growth ${ }^{(4)}$. It also contributes to the net agricultural productivity, economy of the country, employment opportunity to the local community and ensures climate and environmental safety. Deficiency in plant base minerals is an important factor when the reclamation and management practices are performed in acid sulfate soils ${ }^{(5)}$. The reclamation of these soils may be difficult but

*Author of correspondence: <soniahossain_ng@yahoo.com>. 
essential. In order to alleviate the two-folds problem, application of basic slag had made the reclamation processes cost-effective to the farmers.

Basic slag is an excellent soil conditioner, liming agent, provider of trace minerals plus phosphate, calcium, magnesium, manganese and boron, etc. The Si contained in basic slag decreases Mn toxicity, enhances insect and disease resistance, and increases the water-use efficiency, oxidation power of rice roots and the efficiency of phosphorus utilization ${ }^{(6)}$. Despite of some changes in soil properties after a fallow period of 18 years, it is mandatory to check the crop response of the residual soil to recommend this a sustainable technique. The main objective of this study is to assess the long term effectiveness of basic slag application on crop growth.

\section{Materials and Methods}

The potentiality of the acid reclamation measures after 18 years fallow under net house condition was the prime consideration of this present study. Previously, for the simulation studies using concrete tanks, bulk soils from the 1st layer $(0-20 \mathrm{~cm})$, 2nd layer $(20-40 \mathrm{~cm})$ and 3rd layer $(40-60 \mathrm{~cm})$ of Badarkhali (B) and Cheringa (C) series were collected from Purbapukuria of Badarkhali Upazilla and Sarisabari of Chakaria

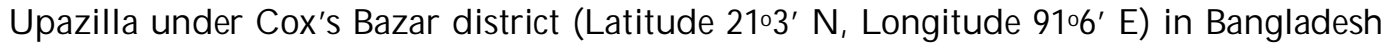
during March 1999(4). About $10 \mathrm{~kg}$ of air-dried coarse sand, which was previously treated with tap water followed by $1 \mathrm{M} \mathrm{HCl}$, and distilled water was put at the bottom of each of the concrete tanks. Thereafter, the soil layers were placed in the concrete tanks $(0.6 \times 0.6 \times$ $0.6 \mathrm{~m}$ ) according to the following arrangement: 1st layer at the top of the concrete tank, followed by the 2nd and 3rd layers. The soils amounting to about 70, 30 and $30 \mathrm{~kg}$ from the 1st, 2nd and 3rd layers, respectively, i.e., a total of $130 \mathrm{~kg}$ soils with aggregate sizes of $<20$ and $20-30 \mathrm{~mm}$, were placed in the concrete tanks for the treatments. Some of the concrete tanks were designed with facilities aimed at analyzing the effect of groundwater at a depth of $50 \mathrm{~cm}$ beneath the soil surface. All the concrete tanks were heavily coated with cement in order to prevent any release of materials ${ }^{(6)}$. The experiments were set up in a completely randomized design (Table 1 ).

Some chemical properties of soil that changed due to rice production after 18 years of fallow period were analyzed following the methods of Jackson(7) (Table 2) in the Department of Soil, Water and Environment, University of Dhaka. Evaluating the soil condition, the basal dose of NPK fertilizers was applied. No other treatments or amendments were applied. The average maximum temperature during the experimental period was $33.2^{\circ} \mathrm{C}$ and average rainfall was $57 \mathrm{~mm}^{(8)}$ in conjuction to the water level maintenance. The soils from the concrete tanks were prepared for the production of rice. The compact top soil was broken with wooden hammer and leached over a period of week using tap water and a suitable soil bed was prepared by puddling for the cultivation of rice. The top soils $(0-20 \mathrm{~cm}$ depth) in each tank, fertilizer containing 
Table 1. Treatments and their combinations for the pot experiments done in $1999^{(4)}$.

\begin{tabular}{|c|c|c|c|c|c|}
\hline \multirow[t]{2}{*}{ Soils } & \multicolumn{2}{|c|}{ Treatment } & \multirow{2}{*}{$\begin{array}{c}\text { Aggregate } \\
\text { size (A: mm) }\end{array}$} & \multirow{2}{*}{$\begin{array}{l}\text { Groundwater } \\
\text { level (Gw: } \mathrm{cm})\end{array}$} & \multirow{2}{*}{$\begin{array}{c}\text { Basic slag rate } \\
\text { (BS: tha) }\end{array}$} \\
\hline & Number & Denotation & & & \\
\hline \multirow{8}{*}{ 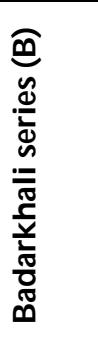 } & $\mathrm{T}_{1}$ & $\mathrm{BA}_{20} \mathrm{Gw}_{0} \mathrm{BS}_{10}$ & $<20$ & 0 & 10 \\
\hline & $\mathrm{T}_{2}$ & $\mathrm{BA}_{20} \mathrm{Gw}_{0} \mathrm{BS}_{20}$ & & & 20 \\
\hline & $\mathrm{T}_{3}$ & $\mathrm{BA}_{20} \mathrm{Gw}_{50} \mathrm{BS}_{10}$ & & 50 & 10 \\
\hline & $\mathrm{T}_{4}$ & $\mathrm{BA}_{20} \mathrm{Gw}_{50} \mathrm{BS}_{20}$ & & & 20 \\
\hline & $\mathrm{T}_{5}$ & $\mathrm{BA}_{30} \mathrm{Gw}_{0} \mathrm{BS}_{10}$ & $20-30$ & 0 & 10 \\
\hline & $\mathrm{T}_{6}$ & $\mathrm{BA}_{30} \mathrm{Gw}_{0} \mathrm{BS}_{20}$ & & & 20 \\
\hline & $\mathrm{T}_{7}$ & $\mathrm{BA}_{30} \mathrm{Gw}_{50} \mathrm{BS}_{10}$ & & 50 & 10 \\
\hline & $\mathrm{T}_{8}$ & $\mathrm{BA}_{30} \mathrm{G} w_{50} \mathrm{BS}_{20}$ & & & 20 \\
\hline \multirow{8}{*}{ 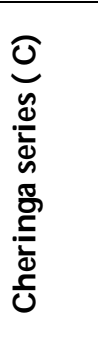 } & $\mathrm{T}_{9}$ & $\mathrm{CA}_{20} \mathrm{Gw}_{0} \mathrm{BS}_{10}$ & $<20$ & 0 & 10 \\
\hline & $\mathrm{T}_{10}$ & $\mathrm{CA}_{20} \mathrm{Gw}_{0} \mathrm{BS}_{20}$ & & & 20 \\
\hline & $\mathrm{T}_{11}$ & $\mathrm{CA}_{20} \mathrm{Gw}_{50} \mathrm{BS}_{10}$ & & 50 & 10 \\
\hline & $\mathrm{T}_{12}$ & $\mathrm{CA}_{20} \mathrm{Gw}_{50} \mathrm{BS}_{20}$ & & & 20 \\
\hline & $\mathrm{T}_{13}$ & $\mathrm{CA}_{30} \mathrm{Gw}_{0} \mathrm{BS}_{10}$ & $20-30$ & 0 & 10 \\
\hline & $\mathrm{T}_{14}$ & $\mathrm{CA}_{30} \mathrm{Gw}_{0} \mathrm{BS}_{20}$ & & & 20 \\
\hline & $\mathrm{T}_{15}$ & $\mathrm{CA}_{30} \mathrm{Gw}_{50} \mathrm{BS}_{10}$ & & 50 & 10 \\
\hline & $\mathrm{T}_{16}$ & $\mathrm{CA}_{30} \mathrm{G}{ }_{50} \mathrm{BS}_{20}$ & & & 20 \\
\hline
\end{tabular}

Composition of basic slag (\%): $\mathrm{SiO}_{2}$ 12.8, $\mathrm{Ca} 20.8, \mathrm{Mg}$ 9.8, $\mathrm{Fe} 11.3, \mathrm{Mn}$ 0.04, $\mathrm{PO}_{4} 0.3$ and others 44.96, pH 9.6 (Laboratory of Soil Science, Inst. For Plant Nutrition and Soil Science, University of Keil, D-24109 Kiel, Germany 1999).

Table 2. Initial properties of Badarkhali and Cheringa acid sulfate soil before and after the applied treatments (aggregate size, groundwater level and basic slag).

\begin{tabular}{|c|c|c|c|c|}
\hline & \multicolumn{2}{|c|}{ Badarkhali series } & \multicolumn{2}{|c|}{ Cheringa series } \\
\hline $\begin{array}{l}\text { Soil } \\
\text { properties }\end{array}$ & $\begin{array}{l}\text { Initial } \\
1998^{(6)}\end{array}$ & $\begin{array}{l}\text { Fallow } 2016 \\
\left.\text { (avg. of } T_{1}-T_{8}\right)\end{array}$ & $\begin{array}{l}\text { Initial } \\
1998^{(6)}\end{array}$ & $\begin{array}{l}\text { Fallow } 2016 \\
\left.\text { (av. of } \mathrm{T}_{9}-\mathrm{T}_{16}\right)\end{array}$ \\
\hline Soil pH (dry, $1: 2.5$ ) & 3.9 & 6.1 & 3.6 & 5.7 \\
\hline $\mathrm{EC}\left(\mathrm{mS} \mathrm{cm}^{-1}\right)$ & 23 & 4.0 & 10.5 & 2.7 \\
\hline Organic carbon $(\%)$ & 1.8 & 1.08 & 2.3 & 1.0 \\
\hline Total N (\%) & 0.01 & 0.02 & 0.01 & 0.05 \\
\hline CN ratio & 15.0 & 20.7 & 16 & 20.1 \\
\hline Available $\mathrm{N}(1.3 \mathrm{M} \mathrm{KCl}: \mathrm{m} \mathrm{mol} / \mathrm{kg})$ & 3.2 & 14.7 & 3.6 & 15.2 \\
\hline $\begin{array}{l}\text { Available } \mathrm{P}\left(0.001 \mathrm{M} \mathrm{H}_{2} \mathrm{SO}_{4}, \mathrm{pH} 3: \mathrm{m}\right. \\
\mathrm{mol} / \mathrm{kg})\end{array}$ & 0.1 & 3.1 & 0.1 & 0.1 \\
\hline Sulfate $\left(\mathrm{BaCl}_{2}: \mathrm{c} \mathrm{mol} / \mathrm{kg}\right)$ & 4.12 & 0.1 & 4.96 & 0.1 \\
\hline $\begin{array}{l}\mathrm{CEC}\left(1 \mathrm{M} \mathrm{CH}_{3} \mathrm{COONH}_{4} \mathrm{pH} 7.0: \mathrm{c}\right. \\
\mathrm{mol} / \mathrm{kg})\end{array}$ & 20.2 & 22.0 & 33.5 & 15.8 \\
\hline
\end{tabular}

$\mathrm{N}, \mathrm{P}$ and $\mathrm{K}$ at the rate of 120, 60 and $80 \mathrm{~kg}$ ha as urea, triple super phosphate (TSP) and muriate of potash (MP), respectively were applied. The full dose of TSP and MP and half of the urea was applied before transplantation. The remaining half of the urea was 
applied in two equal splits, one at the maximum tillering stage of rice and other at the panicle initiation stage.

Twenty five days old seedlings of BRRI 48 and BRRI hybrid dhan 06 were collected from Bangladesh Rice Research Institute, Gazipur. Seedlings were transplanted on 7th May, 2016 at the rate of 3 plants per hill, 3 hills in a row and two rows for each variety in the tank (i.e. $3 \times 2 \times 2=12$ hills per unit of $0.4 \mathrm{~m}^{2}$ tank). These two rows of each variety

were considered as replications. The distances between the hills were $15 \mathrm{~cm}$. The varieties were chosen due to their high yielding capacity, popularity and seasonal availability. The soils in the tanks were irrigated by natural rain and tap water. After 10 - 12 days of seedlings transplantation soil was kept at submerged condition. At the rest of the stages water content was maintained near field capacity. Weeds were removed manually. Adequate plant protection measures like pest control, shading were taken during the growing period. Hilthion 57EC were applied to protect plants from the pest named Longhorned cricket.

The rice plants were allowed to grow for 110 days. The height of the collected plants was recorded using meter scale. Then plant sampling was done by uprooting carefully from the experimental blocks. The plants were put into the plastic bags with proper labeling and brought into the laboratory. Fresh weight was measured using electric balance. Then the samples were first air dried and then oven dried at $70 \pm 5^{\circ}$ for $48 \mathrm{hrs}$. The oven dried weight of the plants was taken using an electric balance. Plant agronomic parameters - panicle length, number of panicle, number of grain per pot, per cent filled grain, weight of filled grains, 1000-grain weight and harvest index were studied in the laboratory. The results of the experiments were calculated and graphically evaluated using Microsoft Excel 2010. All statistical analyses were performed with Minitab version 15.

\section{Results and Discussion}

Plant height and tiller production: Plant height and tiller numbers were found significant on the long term effects of selected treatments $(p \leq 0.05)$ in least significant difference (LSD) and Tukey test. The notations followed by the same letter in Tukey test are not significantly different at $5 \%$ level.

The tallest plant height for BRRI 48 variety in Badarkhali series was $112 \mathrm{~cm}$ and the shortest was $87 \mathrm{~cm}$ and for Cheringa series tallest plant height was $114 \mathrm{~cm}$ and the shortest was $97 \mathrm{~cm}$ (Fig. 1). In panicle initiation stage, the maximum number of tillers were 8.3 in numbers/plant for Badarkhali and the minimum is 5.8 in numbers/plant and maximum 7.5 in numbers/plant for Cheringa soils and minimum 3.8 in numbers/plant (Fig. 1).

For BRRI hybrid dhan 06 the maximum plant height was recorded $118 \mathrm{~cm}$ both in Badarkhali and Cheringa series and lowest plant height was $96 \mathrm{~cm}$ on average for both 
the series. In panicle initiation stage, the maximum number of tillers were 9.1 numbers/ plant and minimum was 4.1 numbers/plant for Badarkhali and maximum 7 numbers/ plant and minimum 2.6 numbers/plant for Cheringa series (Fig. 2).

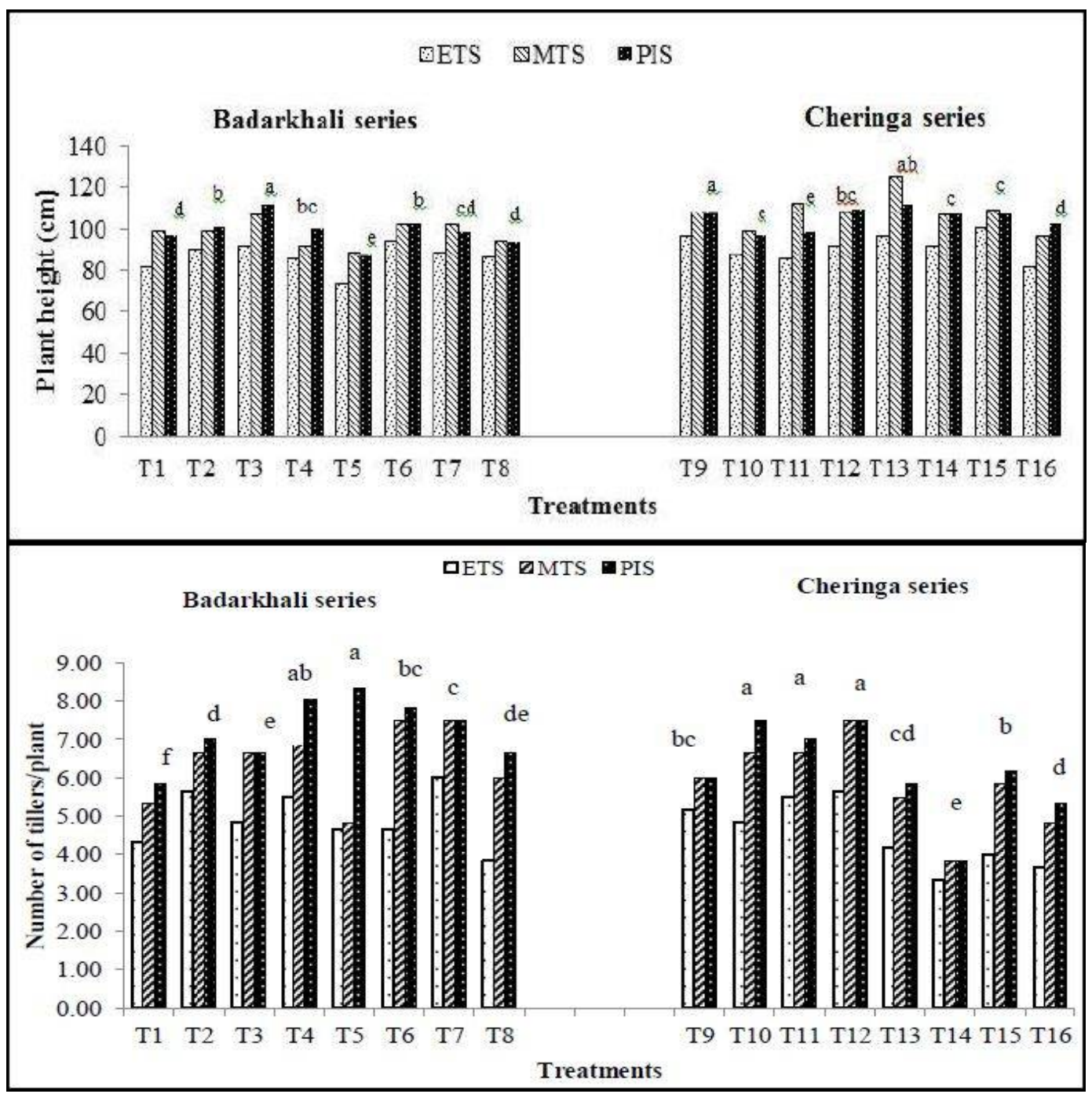

Fig. 1. Long term effects of basic slag application rate, aggregate size and groundwater level treatments on plant height and tiller production at different growth stages of the BRRI 48 rice variety cultivated in two acid sulfate soils. [ETS = Early tillering stage (20-40 days); MTS = Maximum tillering stage (41-70 days); PIS = Panicle initiation stage (71-100 days)].

In both varieties, the plant height was more than the average plant height which was $105 \mathrm{~cm}^{(9)}$. In case of tiller number, the stands might be very dense and tillers were undeveloped. Some tillers died before producing a panicle due to uneven distribution of 
sunlight. Consequently only the main culm produced a panicle. The reasons behind reduced tillering could be nitrogen deficiency, weed competition and application of fungicides ${ }^{(10)}$.

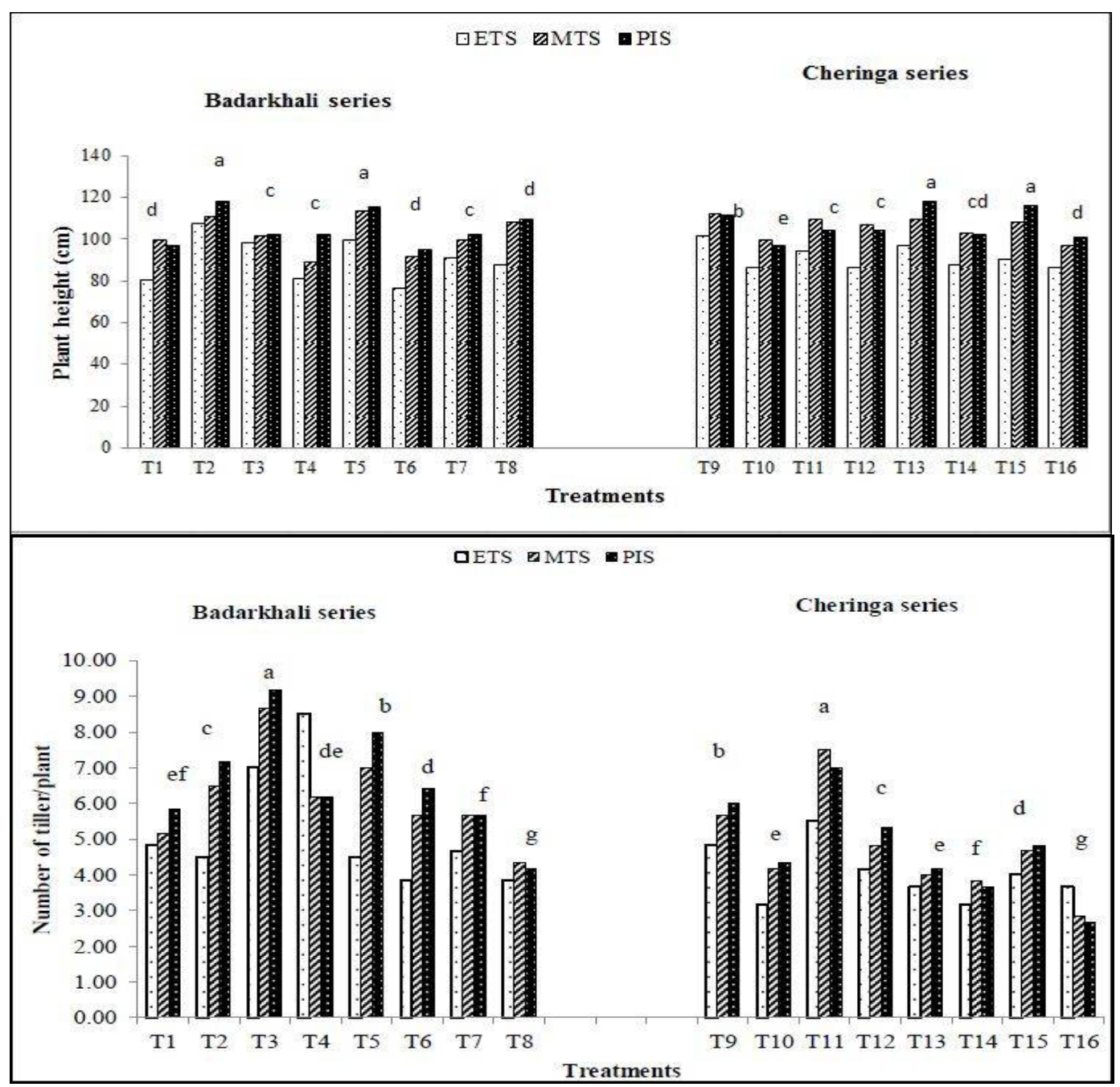

Fig. 2. Long term effects of basic slag application rate, aggregate size and groundwater level treatments on plant height and tiller production at different growth stages of the BRRI hybrid 06 rice variety cultivated in two acid sulfate soils. [ETS = Early tillering stage (20-40 days); MTS = Maximum tillering stage (41-70 days); PIS = Panicle initiation stage (71-100 days).]

Yield and yield components of rice: The analyses of the data on straw and grain yields (Tables 3 and 4) revealed that the average grain and straw yields were more in Badarkhali soil than that of Cheringa soil. The maximum yields for BRRI 48 (grain: 20.05 
$\mathrm{g} \mathrm{m}^{-2}$ and straw: $277.65 \mathrm{~g} \mathrm{~m}^{-2}$ for Badarkhali soil and grain: $10.45 \mathrm{~g} \mathrm{~m}^{-2}$ and straw: $374.75 \mathrm{~g}^{-1}$ $\mathrm{m}^{-2}$ for Cheringa soil) were recorded (Table 3 ).

The maximum yields for BRRI hybrid dhan 06 (grain: $5.88 \mathrm{~g} \mathrm{~m}^{-2}$ and straw: $209.70 \mathrm{~g}$ $\mathrm{m}^{-2}$ for Badarkhali soil and grain: $5.35 \mathrm{~g} \mathrm{~m}^{-2}$ and straw: $337.23 \mathrm{~g} \mathrm{~m}^{-2}$ for Cheringa soil) were recorded (Table 4). The effects of the treatments were not found prominent in grain and straw yields in both the series.

The treatment $T_{1}$ for Badarkhali and $T_{9}$ for Cheringa series were considered as control in calculating \% IOEC (Increased over experimental control) because of aggregate size following the previous reports ${ }^{(4)}$. The grain and straw dry matter production was higher in the Badarkhali soil as compared to Cheringa soil, which might be attributed to the high organic matter content of Badarkhali soil for both the variety BRRI 48 and BRRI hybrid dhan 06.

From the analyses, the per cent filled grain, grain yield and straw yield showed unusual results. In Bangladesh, a high percentage of spikelet sterility usually occurs in Transplanted Aus season (March-June) when the temperature exceeds $35^{\circ} \mathrm{C}$ at anthesis and lasts for more than 1 hour ${ }^{(11)}$. On July, 2016, the average maximum temperature was $33.6^{\circ} \mathrm{C}$ which was above the critical temperature (between 20 and $30^{\circ} \mathrm{C}$ ) and the average maximum humidity was $91 \%{ }^{(12)}$. Moreover, as the temperature rises, accompanied by rainfall or high humidity, possibility of pest and disease attack increases. Empty grains or blanks, can be the result of hot temperature during pollen formation. After flowering, temperatures above $35^{\circ} \mathrm{C}$ can adversely affect pollination ${ }^{(13)}$. Other factors could be stand density, panicle blast, sulfur deficiency and armyworms feeding on developing grains. Grain weight was negatively affected because of drying the field too early before harvesting.

Seedling age is an important element affecting the number of filled grains per panicle, the panicle length, the 1000-grain weight and the grain yield in rice, as reported by Ginigaddara ${ }^{(14)}$. $\mathrm{Li}^{(15)}$ reported that, when rice plants were mechanically transplanted at a 20 days seedling age, the grain yield markedly decreased by $4.66 \%$ compared to that under artificial transplantation.

Based on the values of the harvest index the treatments can be arranged in the following sequence on the growth of BRRI 48:

Badarkhali soil: $\mathrm{T}_{2}\left(\mathrm{BA}_{20} \mathrm{GW}_{0} \mathrm{BS}_{20}\right)>\mathrm{T}_{8}\left(\mathrm{BA}_{30} \mathrm{GW}_{50} \mathrm{BS}_{20}\right)=\mathrm{T}_{7}\left(\mathrm{BA}_{30} \mathrm{GW}_{50} \mathrm{BS}_{10}\right)>\mathrm{T}_{3}$ $\left(\mathrm{BA}_{20} \mathrm{GW}_{50} \mathrm{BS}_{10}\right)>\mathrm{T}_{6}\left(\mathrm{BA}_{30} \mathrm{GW}_{0} \mathrm{BS}_{20}\right)=\mathrm{T}_{1}\left(\mathrm{BA}_{20} \mathrm{GW}_{0} \mathrm{BS}_{10}\right)>\mathrm{T}_{4}\left(\mathrm{BA}_{20} \mathrm{GW}_{50} \mathrm{BS}_{20}\right)=\mathrm{T}_{5}$ $\left(\mathrm{BA}_{30} \mathrm{GW}_{0} \mathrm{BS}_{10}\right)$.

Cheringa soil: $\mathrm{T}_{13}\left(\mathrm{CA}_{30} \mathrm{GW}_{0} \mathrm{BS}_{10}\right)>\mathrm{T}_{16}\left(\mathrm{CA}_{30} \mathrm{GW}_{50} \mathrm{BS}_{20}\right)=\mathrm{T}_{11}\left(\mathrm{CA}_{20} \mathrm{GW}_{50} \mathrm{BS}_{10}\right)>\mathrm{T}_{9}$ $\left(\mathrm{CA}_{20} \mathrm{GW}_{0} \mathrm{BS}_{10}\right)=\mathrm{T}_{12}\left(\mathrm{CA}_{20} \mathrm{GW}_{50} \mathrm{BS}_{20}\right)=\mathrm{T}_{14}\left(\mathrm{CA}_{30} \mathrm{GW}_{0} \mathrm{BS}_{20}\right)=\mathrm{T}_{15}\left(\mathrm{CA}_{30} \mathrm{GW}_{50} \mathrm{BS}_{10}\right)>\mathrm{T}_{10}$ $\left(\mathrm{CA}_{20} \mathrm{GW}_{0} \mathrm{BS}_{20}\right)$. 


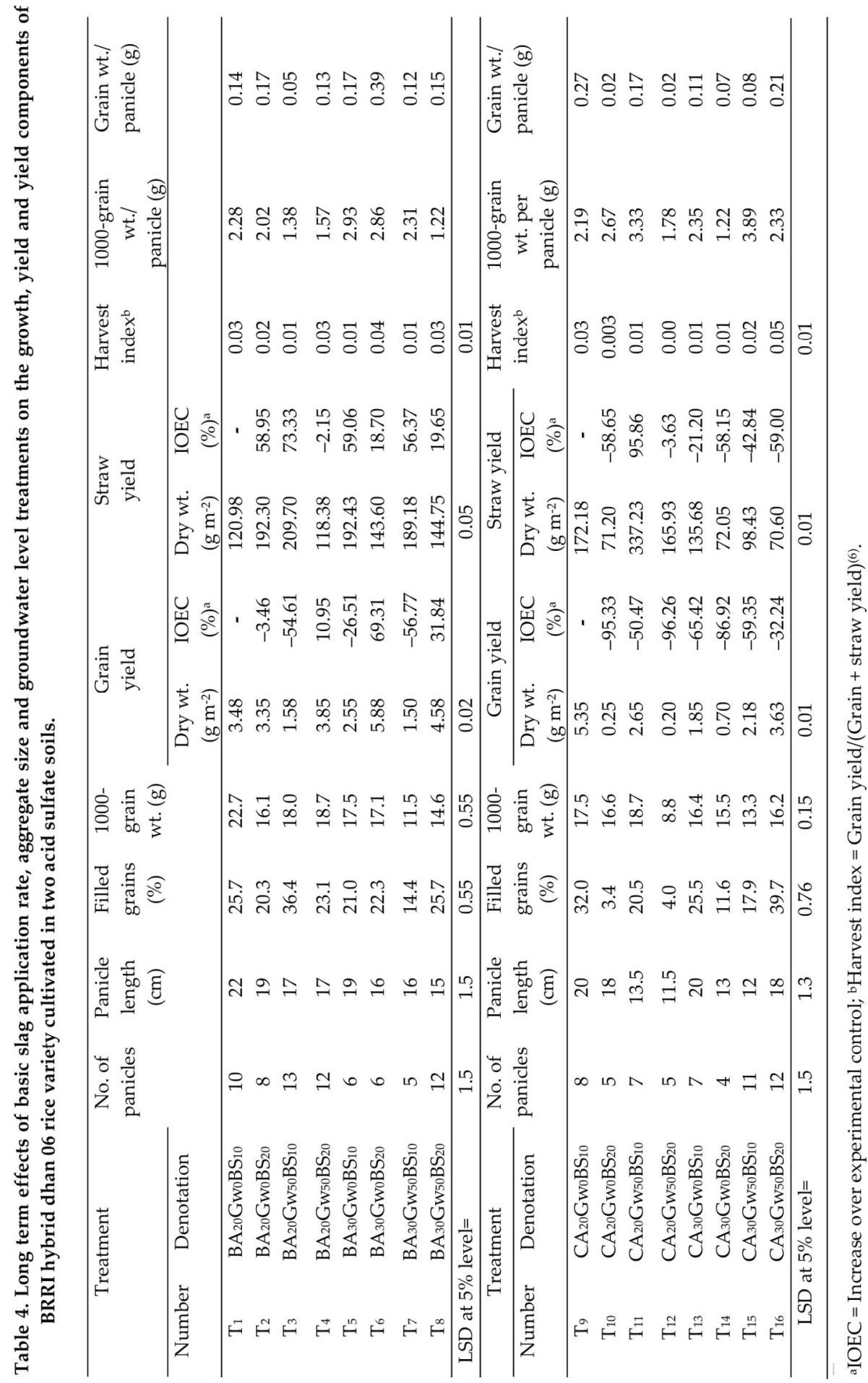


Based on the values of the harvest index the treatments can be arranged in the following sequence on the growth of BRRI hybrid dhan 06:

Badarkhali soil: $\mathrm{T}_{6}\left(\mathrm{BA}_{30} \mathrm{GW}_{0} \mathrm{BS}_{20}\right)>\mathrm{T}_{1}\left(\mathrm{BA}_{20} \mathrm{GW}_{0} \mathrm{BS}_{10}\right)=\mathrm{T}_{4}\left(\mathrm{BA}_{20} \mathrm{GW}_{50} \mathrm{BS}_{20}\right)=\mathrm{T}_{8}$ $\left(\mathrm{BA}_{30} \mathrm{GW}_{50} \mathrm{BS}_{20}\right)>\mathrm{T}_{2}\left(\mathrm{BA}_{20} \mathrm{GW}_{0} \mathrm{BS}_{20}\right)>\mathrm{T}_{3}\left(\mathrm{BA}_{20} \mathrm{GW}_{50} \mathrm{BS}_{10}\right)=\mathrm{T}_{5}\left(\mathrm{BA}_{30} \mathrm{GW}_{0} \mathrm{BS}_{10}\right)=\mathrm{T}_{7}$ $\left(\mathrm{BA}_{30} \mathrm{GW}_{50} \mathrm{BS}_{10}\right)$

Cheringa soil: $\mathrm{T}_{16}\left(\mathrm{CA}_{30} \mathrm{GW}_{50} \mathrm{BS}_{20}\right)>\mathrm{T}_{9}\left(\mathrm{CA}_{20} \mathrm{GW}_{0} \mathrm{BS}_{10}\right)>\mathrm{T}_{15}\left(\mathrm{CA}_{30} \mathrm{GW}_{50} \mathrm{BS}_{10}\right)>\mathrm{T}_{11}$ $\left(\mathrm{CA}_{20} \mathrm{GW}_{50} \mathrm{BS}_{10}\right)=\mathrm{T}_{13}\left(\mathrm{CA}_{30} \mathrm{GW}_{0} \mathrm{BS}_{10}\right)=\mathrm{T}_{14}\left(\mathrm{CA}_{30} \mathrm{GW}_{0} \mathrm{BS}_{20}\right)>\mathrm{T}_{10}\left(\mathrm{CA}_{20} \mathrm{GW}_{0} \mathrm{BS}_{20}\right)>\mathrm{T}_{12}$ $\left(\mathrm{CA}_{20} \mathrm{GW}_{50} \mathrm{BS}_{20}\right)$.

The above results indicate that the application of treatments is effective for the improvement of soil condition but shows variation in plant growth. The major reasons were late transplantation, climatic condition like humidity and temperature during crop growth.

\section{Conclusion}

The major investigation after 18 years of fallow acid sulfate soils revealed that, the soils reclaimed properly for crop growth. But the growth and yield parameters of rice grown were affected by temperature variation, unusual rainfall and excessive humidity. So, basic slag application in acid sulfate soils could be recommended as a sustainable approach for the cultivation of rice. The experiment revealed that not only the improvement of soil but also the environmental factors and proper maintenance should be given equal importance to get maximum crop yield.

\section{Acknowledgement}

The first author (MM) is grateful to the Ministry of Science and Technology, Government of the People's Republic of Bangladesh, for providing The National Science and Technology Fellowship to financially support this research.

\section{References}

1. FAO (Food and Agricultural Organization of the United Nations) 2015. FAO and the 17 Sustainable Development Goals, Food and Agriculture Organization of the United Nations, Rome. pp. 3.

2. Khan HR 2000. Problem, prospects and future directions of acid sulfate soils. An International Conference on Remade Lands, 2000. A. Brion and R. W. Bell. (ed.) Promaco Convention Pvt. Ltd., Perth, Australia. pp. 66-67.

3. Fertilizer Recommendation Guide 2012. Bangladesh Agricultural Research Council (BARC), Dhaka. pp. 28.

4. Khan HR, MMA Bhuiyan, SM Kabir, HP Blume, Y Oki and T Adachi 2007. Consequences of basic slag on soil $\mathrm{pH}$, calcium and magnesium status in acid sulfate soils under various water contents. J. Biol. Soc. Sci. 7: 896-903. 
5. Jintaridth B 2006. The role and effectiveness of phospho-microorganisms with rock phosphate. The 18th World Congress of Soil Science Abstract, July 9-15, 2006. Philadelphia, Pennsylvania, USA. pp. 681.

6. Khan HR, MMA Bhuiyan, SM Kabir, HP Blume, Y Oki and T Adachi 2006. Effects of selected treatments on the production of rice in acid sulfate soils in a simulation study. Jpn. J. Trop. Agr. 50(3): 109-115.

7. Jackson ML 1973. Soil Chemical Analysis. Prentice Hall of India Pvt. Ltd., New Delhi. pp. 38226.

8. Bangladesh Meterological Department 2016. Forecast of the period 8.5.16-31.8.16 (AgroMeterology Division). Meteorological Complex, Agargaon, Dhaka-1207.

9. BRRI (Bangladesh Rice Research Institute) 2015. Modern rice cultivation. $18^{\text {th }}$ edition. BRRI, Gazipur. pp. 8.

10. Espino L 2014. Rice yield components. UC Rice Blog. California Rice Production. Agriculture and Natural Resources. University of California. http://ucanr.edu/blogs/blogcore/ postdetail.cfm? postnum $=14826$

11. Lal R, MVK Sivakumar, SMA Faiz, AHMM Rahman and KR Islam (eds.) 2011. Climate Change and Food Security in South Asia. Springer Dordrecht Heidelberg, New York, London. pp. 426.

12. Bangladesh Meterological Department 2016. Forecast of the period 8.7.16 - 14.7.16 (AgroMeterology Division). Meteorological Complex, Agargaon, Dhaka-1207.

13. Strand L 1993. Integrated Pest Management for Rice. 2nd Ed. University of California. Statewide Integrated Pest Management Project. Division of Agriculture and Natural Resources. USA. pp. 15.

14. Ginigaddara GAS and SL Ranamukhaarachchi 2011. Study of age of seedlings at transplanting on growth dynamics and yield of rice under alternating flooding and suspension of irrigation of water management. Recent Res. in Sci. and Tech. 3: 76-88.

15. Li J, HC Zhang, Y Chang, JL Gong, ZH Guo and QG Dai 2011. Characteristics of photosynthesis and matter production of rice with different planting methods under highyielding cultivation condition. Acta Agron. Sin. 37: 1235-1248. 